\title{
Development of Learning Media Based on Cross Puzzle Game in Science Learning to Improve Learning Outcomes
}

\author{
Ornella Alika1 ${ }^{*}$, Elvira Hoesein Radia ${ }^{1}$ \\ ${ }^{1}$ Elementary School Teacher Education Study Program, Faculty of Teacher Training and Education, Satya Wacana Christian University, \\ Salatiga, Indonesia.
}

\section{DOI: $10.29303 /$ jppipa.v7i2.667}

\section{Article Info}

Received : February 28th 2021

Revised : April 1th, 2021

Accepted: April 5th 2021

\begin{abstract}
The interest of students in learning Science in Elementary Schools will increase if the teacher uses different learning media than usual. This research and development aim to create a product in the form of science learning media for grade 5 of elementary schools on the material of Animal Classification by the Type of Food as an effort to improve the student-learning outcomes. This study uses the 4D model adapted from the theory of Borg and Gall. This Cross Puzzle Game Media utilizes technology to develop a science-learning media. Two experts who are competent in their fields, namely Material Experts and Media Experts have validated this media. The results of the validation of material results from the media experts reached an average of 3,9 with the valid category, while the material experts got an average of $90 \%$ with the very decent category. So that, the assessment results of the Cross Puzzle game are valid and worthy of being used as a learning media to improve the student-learning outcomes.
\end{abstract}

Keywords: Science learning media; Cross puzzle Game; Learning outcomes

Citation: Alika, O., \& Radia, E. (2021). Development of Learning Media Based on Cross Puzzle Game in Science Learning to Improve Learning Outcomes. Jurnal Penelitian Pendidikan IPA, 7(2), 173-177. doi:https://doi.org/10.29303/jppipa.v7i2.667

\section{Introduction}

Education is the most important thing for anyone, with education can shape a person into character, and have a broad view of the future. There is a formal education level in schools, the most basic education of students, namely elementary school, which has the aim of building students' basic knowledge. During the Covid-19 pandemic, the learning process in the education sector was hampered. One of the government policies due to the Covid-19 pandemic is to conduct distance learning as a form of reducing cases of the increase in the Covid 19 virus. With this policy, teachers are required to be more creative and innovative in carrying out the learning process. The existence of the Covid-19 pandemic has had a major influence in the learning process around the world, efforts are used to keep education running properly and correctly, so that efforts are made to use technology in learning, especially online technology which refers to technological tools so that users can access information and communicate well so that the learning process continues well (Sukendro et al., 2020)

Learning is not only based on teaching materials available in one source such as books. The use of learning media can be a means of supporting student learning. Learning media is a physical tool that is used and utilized to convey the content of learning material. Examples of learning media such as books/modules, tape recorders, cassettes, video recorders, video cameras, television, radio, films, slides, photos, pictures, and computers (Taufiq et al., 2014). In addition to trying to find learning methods, education experts also change the personalities and abilities of 
students, which aims to make education more appropriate by applying new technologies applied to education so that the creativity and talents of students can increase (Hamidi et al., 2011). Online that is currently being carried out requires maximum use of technology, this is intended so that learning continues and students can receive learning material as usual. Creative media as a support for the learning process, learning media are also very useful as a means of attracting students to take part in distance learning. The influence of learning media on students is very large because it helps students increase their knowledge and understanding (Sari et al., 2019).

The use of learning media when applied to students can improve student learning outcomes (Mureiningsih, 2014), the use of media in learning will also foster positive attitudes from both teachers and students, due to increased confidence in teachers and students to use technology in education (Abdulrahaman et al., 2020), in addition to conveying the content of learning material. The use of instructional media is one of the efforts of a teacher to improve the quality of education. Learning media if used appropriately can help teachers convey material content to students easily, so currently the use of learning media is highly recommended, so as not to cause misunderstandings for students and teachers (Amriani, 2018). This opinion is in line with the main function of learning media in consisting of six processes conveyed by Sudjana (2002), namely: (1) learning media as a tool to create effective learning situations, (2) an integral part of the overall teaching and learning situation, (3) learning media has objectives that are integral to the content of the lesson, (4) it is not only a means of entertainment or a complement, (5) but aims to accelerate the learning process and help students understand the learning material delivered by the teacher, and (7) more importantly, namely to improve the quality of student learning.

In the content of Natural Sciences lessons, it is highly recommended and implemented to take advantage of learning media, as a substitute for the role of the teacher to provide information or deliver material on science learning, learning media should be simple and practical. So that in general the learning media in the science learning process has a function to (1) aids for more effective learning (2) parts that are integral in teaching situations (3) Using concrete basic concepts so as to reduce misunderstanding of students in receiving material (4) and motivation of students to be more enthusiastic in participating in learning.

The use of newly used learning media, students can have new experiences and have a high curiosity. In addition, if the main concepts in learning, students are not only focused on the final result but also on the process when they see, hold, and complete themselves in their own way (Hidayati \& Wuryandari, 2012), but in reality, teachers do not really understand how to use learning media or make learning media with their own innovations, so there are still teachers who do not use learning media in the learning process. In fact, many schools have facilitated learning media that can be used by teachers and students in the science learning process. This fact is in line with the results of research by Amran and Muslimin (2017) that the fact is that teachers have not been maximal in designing and carrying out the learning process on science learning content.

In learning science, innovative learning media are needed to attract students to learn science by using educational game-based learning media, in the form of crossword puzzles games. Learning using the Cross Puzzle game media can attract students 'interest because students feel learning while playing, to be able to sharpen students' brains, and to give a relaxed but challenging impression with various levels of problem difficulty. The Cross Puzzle Game helps students memorize science material classifying animals based on the type of food they eat.

The way to play this crossword puzzle game is to fill in the column boxes with the letters that match the questions. This is in accordance with the opinion of Khalilullah (2012) "A crossword puzzle is a game in which the game method is to fill empty spaces in the shape of a box with letters to form a word according to the instructions".

The crossword puzzle game is an educational game. In this crossword educational educational game, it is not only in the form of text, but there is material that students can understand before working on the problem. In addition, the game of Cross Puzzle helps students to increase their sense of honesty, discipline, curiosity and also the character of students (Wulan et al., 2019).

\section{Method}

This type of research is included in research and development (R\&D), which is a method for producing certain products and testing these products. The research procedure developed in this study was adapted from the development procedure submitted by Borg and Gall (Sukmadinata, 2013), namely the Borg and Gall Research and Development Procedure Steps as follows: 1) Research and Data Collection, 2) Planning, 3 ) Development of Product Draft, 4) Initial Field Trial, 5) Revision of Initial Trial Results, 6) Field Trial, 7) Product Improvement of Field Test Results, 8) Field Implementation Test, 9) Final Product Completion, and 10) Dissemination and 
Implementation. The development model used in this research is the 4D model. According to Trianto (2013: 189 ), the 4D Models development model consists of 4 development stages. The stages in the $4 \mathrm{D}$ Model development process are: Define, Design, Develop, Disseminate.

In the first stage of defining, data was collected. Data collection techniques used are: interviews or through journals, books, magazines, and other relevant sources to find out information on research results related to learning materials and theory and media to be developed in the form of crossword puzzle games. The second stage of planning, observing and understanding problems in the form of obstacles to students in learning science from the results of the data collection stage that has been carried out, then selecting the media or game products to be developed. The third stage of product development is based on the results of data collection and product planning, the researchers compile an initial draft, design the product to be developed, determine the basic competencies, materials, and questions in the crossword puzzle game. In the development stage, validation is carried out by competent experts.

The next stage is to make improvements based on input and suggestions from experts, then a trial is carried out to test and improve the product. The last stage, namely the distribution at this stage was not carried out, and the trial of crossword puzzle game products was only carried out by three media and material experts, due to time and situation considerations in elementary schools that did not allow for direct trials or trials through online learning. . In this study, not entirely using the ten steps of development from Borg \& Gall.

At the product development stage, it will pass an expert validation test, the products that are validated are the material and crossword puzzle game questions. The validation data that came from the six experts were in the form of questionnaires, criticisms, and suggestions. The results of the material experts aim to make the learning material developed by the researcher into a quality product, while the results of the media experts aim to obtain data on the feasibility of learning media based on crossword puzzle games in science learning from the aspect of the media.

The data collection instruments used in this study included questionnaire sheets from material experts and media experts. The questionnaire validation sheet uses a Likert scale with five alternative choices, including: Strongly Agree, Agree, Doubt, Disagree, and Strongly Disagree. The following is a closed questionnaire formula to test the validity of the material:

$$
X=\frac{\text { Actual Score }}{\text { ideal Score }} \times 100 \%
$$

Annotation

$\mathrm{X} \quad$ : Percentage figures

Actual Score : Score given by expert validators

Ideal Score : The maximum score is the product of the number of items of each item.

The evaluation of the validity of the material on development products is shown in Table 1.

Table 1. Validation Assessment Criteria

\begin{tabular}{lll}
\hline No & Score Percentage $(\%)$ & Interpretation \\
\hline 1 & $\mathrm{P}>80$ & Very Valid \\
2 & $61<\mathrm{P} \leq 80$ & Valid \\
3 & $41<\mathrm{P} \leq 60$ & Enough Valid \\
4 & $20<\mathrm{P} \leq 40$ & InValid \\
5 & $\mathrm{P} \leq 20$ & Very Invalid \\
\hline
\end{tabular}

The assessment of the development of learning media for the crossword puzzle game was assessed by three material experts with a minimum score of good or valid with a percentage obtained more than $61 \%$ and below $80 \%$.

The assessment of the feasibility of product development media is assessed using the following criteria table (Ratumanan \& Lauren, 2011).

Table 2. Material eligibility criteria

\begin{tabular}{lll}
\hline No & eligibility criteria & Interpretation \\
\hline 1 & Not Eligibil & $\geq 1.0-\leq 1.8$ \\
2 & Less Eligibil & $1.8 \geq \mathrm{SV} \leq 2.6$ \\
3 & Enough Eligibil & $2.6 \geq \mathrm{SV} \leq 3.4$ \\
4 & Eligibil & $3.4 \geq \mathrm{SV} \leq 4.2$ \\
5 & Very Eligibil & $4.2 \geq \mathrm{SV} \leq 5.0$ \\
\hline
\end{tabular}

The assessment of the learning media for the crossword puzzle game was considered feasible by three media experts with an average minimum value of Eligible with the interpretation obtained by $3.4 \geq \mathrm{SV}$ $\leq 4.2$.

\section{Results and Discussion}

Based on the results of research using the $4 \mathrm{D}$ development model in the first stage of definition, information was obtained about the low use of instructional media in science subject content in grade 5 elementary school, and the problem of student interest in learning science. Then after obtaining the information, the second stage is planning to choose the right media in the form of a developed game product, then arranging crossword puzzle games and searching for various kinds of reference books according to the game product. The third stage of development is by making game-based learning media in class 5 elementary school science learning. The product of the crossword puzzle game consists of 3 levels, the first 
level consists of 5 questions with a time of 2 minutes, while the second level consists of 10 questions in 4 minutes, and the last level consists of 15 questions with a time of 6 minutes. After the learning media product has been completed, then at this stage, validation is carried out by media and material experts. The results of the material expert validation stage are as follows.

Tabel 3. The Results of the Material Expert Validation Stage

\begin{tabular}{lllll}
\hline \multirow{2}{*}{ Aspect } & \multicolumn{3}{c}{ Validation Score } & Category \\
\cline { 2 - 4 } & Val.1 & Val.2 & Val.3 & \\
\hline Question & 32 & 30 & 27 & Very Valid \\
Language & 17 & 14 & 14 & Very Valid \\
Implementation & 25 & 29 & 29 & Very Valid \\
Total & 74 & 73 & 70 & Very Valid \\
Result & $92 \%$ & $91 \%$ & $87 \%$ & Very Valid \\
\hline
\end{tabular}

Learning media based on the Cross Puzzle Game for the material validation stage carried out by 3 material experts in science learning class 5 obtained a score $(92+91+87) \%: 3=90 \%$ in the very valid category, while for the results of the expert validation stage media as follow.

Tabel 4. Hasil dari tahap validasi ahli media

\begin{tabular}{lllll}
\hline \multirow{2}{*}{ Aspect } & \multicolumn{3}{l}{ Validation Score } & Category \\
\cline { 2 - 4 } & Val.1 & Val.2 & Val.3 & \\
\hline $\begin{array}{l}\text { Software } \\
\text { engineering }\end{array}$ & 32 & 36 & 21 & Eligibil \\
$\begin{array}{l}\text { Visual } \\
\begin{array}{l}\text { Communication } \\
\text { Total }\end{array}\end{array}$ & 39 & 45 & 37 & Eligibil \\
Average & 71 & 81 & 58 & Eligibil \\
\hline
\end{tabular}

Based on the results of the above validation, it is known that the learning media based on the Cross Puzzle Game in science learning in grade 5 get a score $(3.9+4.5+3.2): 3=3.9$ in the proper category, because the value is $3.9<4.2$, the learning media for the Educational Game The Cross Teki is included in the Eligible category based on the assessment of 3 media experts.

Regarding the results of assessments from media experts and material experts, media which can be seen in Table 1 and Table 2, learning based on the Cross Puzzle game is feasible and can improve student learning outcomes, these results are in line with relevant researched by (Utami, 2018) entitled "Development of Learning Media for Educational Games Crosswords in Android-Based Accounting as an Effort to Increase Learning Activities for Class $X$ Students of Accounting 2 State Vocational High School 2 Magelang Academic Year 2017/2018" as well as relevant researched by (Maftakhun, 2020) entitled "Development of Learning Media for Android-based crossword puzzles in Indonesian Language Subjects".
The two studies obtained data that was seen from the differences in learning outcomes of students when using learning media for the Cross Puzzle Game, which could provide an increase in student learning outcomes, compared to not using the Cross Puzzle game.

\section{Conclusion}

Elementary school science problem solving can be carried out in the following steps: (1) defining, planning, developing, expert validation and disseminating learning media for the Cross Puzzle Game; (2) This Cross Puzzle Game presents science material on animal classification based on the type of food in grade 5 elementary school. This game consists of 3 levels and when working there is a different time in each level; (3) The results of the validity of the media and material regarding the development of learning media products for the Cross Puzzle Game get a good response, the results of the media experts reach an average of 3.9 in the feasible category, while the material experts get an average score of $90 \%$ with very valid category; (4) The Cross Puzzle Game is one of the solutions to overcome the interest of students which will have an impact on the learning outcomes of students, besides that the Cross Puzzle Game is not just an ordinary game but children can play and learn at the same time. This game can also train the focus, speed, and accuracy of students in answering questions with good results because in the Cross Puzzle game questions there is a time in each level; (5) The fact is that the availability and use of science learning media is inadequate and so that the learning media has not been maximally utilized by the teacher, as a result the learning process in the classroom is not fully effective and maximized because students only focus on two sources, namely teachers and student books.

\section{Acknowledgments}

Thank you to the Elementary School Teacher Education Study Program, Teaching Faculty of Education, Satya Wacana Christian University Salatiga for providing the opportunity for researchers to carry out this research. Thank you to the schools in Dukuh District, Salatiga City, for being willing to provide information.

\section{References}

Abdulrahaman, M. D., Faruk, N., Oloyede, A. A., Surajudeen-Bakinde, N. T., Olawoyin, L. A., Mejabi, O. V., Imam-Fulani, Y. O., Fahm, A. O., \& Azeez, A. L. (2020). Multimedia tools in the 
teaching and learning processes: A systematic review. In Heliyon. 6(11). Elsevier Ltd. doi:https://doi.org/10.1016/j.heliyon.2020.e0531 $\underline{2}$

Amran, M. \& Muslimin. (2017). Peningkatan Hasil Belajar dengan Menggunakan Media KIT IPA di SD Negeri Mapala Makasar. Jurnal Office, 3(1). doi: $\quad$ https://doi.org/10.26858/jo.v3i1.3465. [Indonesian]

Amriani. (2014). Pengaruh Penggunaan Media Pembelajaran Terhadap Minat Belajar Siswa Pada Mata Pelajaran Pai Siswa SD Inp Lasepang Kecamatan Bantaeng Kabupaten Bantaeng. Repositori UIN Alauddin Makassar. doi: http://dx.doi.org/10.24014/an-nida.v37i1.309. [Indonesian]

Hamidi, F., Kharamideh, Z. M., \& Ghorbandordinejad, F. (2011). Comparison of the training effects of interactive multimedia (CDs) and non-interactive media (films) on increasing learning speed, accuracy and memorization in biological science course. Procedia Computer Science, 3, 144-148. doi: https://doi.org/10.1016/j.procs.2010.12.025.

Hidayati, N., \& Wuryandari, A. I. (2012). Media Design for Learning Indonesian in Junior High School Level. Procedia - Social and Behavioral Sciences, 67,490-499.doi:

https://doi.org/10.1016/j.sbspro.2012.11.354. [Indonesian]

Khalilullah, M. (2012). Permainan Teka-Teki Silang Sebagai Media dalam Pembelajaran Bahasa Arab (Mufradat). Jurnal Pemikiran Islam. 1 (37). [Indonesian]

Maftakhun (2020). Pengembangan Media Pembelajaran Teka-Teki Silang Berbasis ANDROID Pada Mata Pelajaran Bahasa Indonesia. IAIN Salatiga Repository. (n.d.). Retrieved March 19, 2021, from http://erepository.perpus.iainsalatiga.ac.id/9202/. [Indonesian]

Ratumanan, G.T. \& Laurens, T. (2011). Evaluasi Hasil Belajar pada Tingkat Satuan Pendidikan. Surabaya: UNESA University Pres. [Indonesian]

Sari, A. C., Fadillah, A. M., Jonathan, J., \& Prabowo, M. R. D. (2019). Interactive gamification learning media application for blind children using android smartphone in Indonesia. Procedia Computer Science, 157, 589-595. doi:https://doi.org/10.1016/j.procs.2019.09.018

Sudjana, N. (2002) Dasar-dasar Proses Belajar Mengajar, Bandung: Sinar Baru Algensindo. [Indonesian]

Sukendro, S., Habibi, A., Khaeruddin, K., Indrayana, B., Syahruddin, S., Makadada, F. A., \& Hakim, H. (2020). Using an extended Technology Acceptance Model to understand students' use of e-learning during Covid-19: Indonesian sport science education context. Heliyon, 6(11). doi:https://doi.org/10.1016/j.heliyon.2020.e0541 0 .

Sukmadinata, N.S. (2013). Metode Penelitian dan Pengembangan. Bandung: Remaja Rosdakarya. [Indonesian]

Taufiq. (2014). Pengembangan Media Pembelajaran IPA Terpadu Berkarakter Peduli Lingkungan Tema Konservasi Berpendekatan Science Edutainment. Jurnal Pendidikan IPA Indonesia, 1(2) doi: https://doi.org/10.15294/jpii.v3i2.3113. [Indonesian]

Utami, N. S. (2018). Pengembangan Media Pembelajaran Game Edukatif Teka-Teki Silang Akuntansi Berbasis Android Sebagai Upaya Peningkatan Aktivitas Belajar Siswa Kelas X Akutansi 2 SMK Negeri 2 Magelang Tahun ajaran 2017/2018 - Lumbung Pustaka UNY. (n.d.). Retrieved March 6, 2021, from https://eprints.uny.ac.id/58399/. [Indonesian]

Wahyu, Y., Edu, A., \& Nardi, M. (2020). Problematika Pemanfaatan Media Pembelajaran IPA di Sekolah Dasar. Jurnal Penelitian Pendidikan IPA, 6(1), 107-112. doi: https://doi.org/10.29303/jppipa.v6i1.344. [Indonesian] 